\title{
An assessment of the energy inputs and greenhouse gas emissions in sugar beet (Beta vulgaris) production in the UK
}

\author{
J. Tzilivakis ${ }^{\mathrm{a}}$, D.J. Warner ${ }^{\mathrm{a}, *}$, M. May ${ }^{\mathrm{b}}$, \\ K.A. Lewis ${ }^{\mathrm{a}}$, K. Jaggard ${ }^{\mathrm{b}}$ \\ a Agriculture and Environment Research Unit, University of Hertfordshire, Hatfield, Herts, AL10 9AB, UK \\ b Broom's Barn Research Station, Higham, Bury St Edmunds, Suffolk, IP28 6NP, UK
}

Received 16 December 2003; received in revised form 22 June 2004; accepted 15 July 2004

\begin{abstract}
Reducing the energy derived from fossil fuels within agricultural systems has important implications for decreasing atmospheric emissions of greenhouse gases, thus assisting the arrest of global warming. The identification of crop production methods that maximise energy efficiency and minimise greenhouse gas emissions is vital. Sugar beet is grown in a variety of locations and under a variety of agronomic conditions within the UK. This study identified thirteen production scenarios, representative of over $90 \%$ of the UK beet crop, which included five soil types, nine fertiliser regimes and nine crop protection strategies. The fossil energy input, the overall energy efficiency and the global warming potential (GWP) of each production scenario was assessed. This study did not consider the processing of the beet to extract sugar.

The overall energy input of the UK beet crop ranges between 15.72 and $25.94 \mathrm{GJ} / \mathrm{ha}$. It produces between 7.3 and 15.0 times as much energy in dry matter at the sugar factory gate as consumed in its production, with an average ratio of 9.7. It has an average GWP of 0.024 eq. $\mathrm{t} \mathrm{CO}_{2}$ per tonne of clean beet harvested, equivalent to 0.0062 eq. $\mathrm{CO}_{2}$ per GJ output. The energy input into each scenario was dictated largely by the energy associated with crop nutrition. The smallest energy inputs per hectare were to crops grown under organic
\end{abstract}

\footnotetext{
* Corresponding author. Tel.: +44 1707 286075; fax: +44 1707284185.

E-mail address: d.j.warner@herts.ac.uk (D.J. Warner).
} 
conditions or conventional crops grown on fertile soils (clay loam, silt or peat) or sand soil with broiler manure applied. Those crops with the greatest energy input were grown on sand soil that was irrigated and had mineral fertiliser applied. Although the organic scenario grown on sandy loam soil had one of the smallest energy inputs per hectare, the low yield meant that the energy input was similar per tonne of beet harvested to the conventional crops grown on sandy loam soil. The extra distance travelled by organic beet from the farm to the factory increased the energy input per tonne above that of the conventional scenarios. The GWP was smallest for the conventional crops on the fertile peat and silt soils and greatest on the irrigated sand soils and the sandy loam soils. The organic scenario had a similar GWP to the conventional scenarios on sandy loam to the farm gate, although the greater diesel requirement for transport increased the GWP overall. The GWP per GJ of output for sugar beet in England is similar to published values for wheat.

(C) 2004 Elsevier Ltd. All rights reserved.

Keywords: Sugar beet; Energy efficiency; Global warming; Sustainable agriculture

\section{Introduction}

Burning fossil fuels results in the emission of carbon dioxide $\left(\mathrm{CO}_{2}\right)$, nitrous oxide $\left(\mathrm{N}_{2} \mathrm{O}\right)$ and methane $\left(\mathrm{CH}_{4}\right)$ that act as barriers to thermal radiation and prevent it from leaving the Earth's atmosphere, the so-called 'greenhouse effect' (IPCC, 1997). As a consequence, the global mean temperature has increased during the past 100 years and raised concerns over global warming and uncertainty over future impacts on the climate (Pimentel et al., 1996). A reduction in greenhouse gas emissions by minimising the quantity of fossil fuels burnt is therefore essential to arrest global warming. Although the increased use of agricultural inputs in modern farming has resulted in an increase in the energy inputs for fertiliser and crop protection chemicals, higher yields have increased the energy output per unit area and per unit of input (Pimentel et al., 1973). The current policy within agriculture seeks to develop crop production systems that minimise fossil energy input for a high level of output (Dalgaard et al., 2000). In 2002, 169,043 ha were devoted to sugar beet (Beta vulgaris) production in the UK (DEFRA, Agricultural Statistics, 2003), an important component of the UK arable sector. The impact of the UK sugar beet crop on the environment and, for the purpose of this study, the atmosphere, requires scrutiny. This study uses two methods to assess the environmental impact of the UK sugar beet crop. Firstly, energy balance techniques described in Hülsbergen and Kalk (2001) were used to examine the quantity of energy input relative to energy output for the crop as a whole. Because the crop is grown in many different ways, we have represented this by 13 production scenarios, estimated to include $90 \%$ of current production methods in the UK. Secondly, the overall global warming potential (GWP), an index that describes the relative warming of a unit mass of a greenhouse gas in comparison to the same mass of carbon dioxide (Maunder, 1992), was calculated for each scenario. The results are discussed with respect to optimising the energy efficiency of the UK sugar beet crop and minimising greenhouse gas emissions. 


\section{Methods}

\subsection{Description of scenarios}

The proportion of the areas grown under each crop production regime within the UK and their expected average yields are given in Table 1. Scenarios I-XII are under conventional production, scenario XIII is organic. Scenarios I-VI are grown on sand, VII-XIII on sandy loam, IX on clay loam, X on silt and XI and XII on peat. The nutrition, cultivation and pesticide regimes for each scenario are summarised in Tables 1-3, respectively. Scenarios I-IV are irrigated and scenario VI is under minimum tillage. To control wind erosion, Scenarios III and XI have a spring barley cover crop drilled at the end of February and an application of the herbicide Fusilade $^{\circledR}$ (fluazifop-p-butyl) in late April or early May to remove it.

\subsection{Energy balance}

The energy balance was based on the technique described in Hülsbergen and Kalk (2001) and considered the input of fossil energy into the system. The input from manual labour and from the sun was not included. Beet tops were assumed to be re-invested within the field system and thus excluded from the overall output for each scenario. The energy requirements for each production scenario (expressed as megajoules per hectare $(\mathrm{MJ} / \mathrm{ha})$ ) were divided into four sections: crop protection, nutrition, cultivations and culture. The sub-sections are further divided by:

i. energy for the manufacture of crop protection chemicals and fertilisers (including packaging and transport to the farm);

ii. energy required for carrying out of field operations. Each operation was assigned a value based on the type and working width of machine and in the case of tillage operations, the operating depth and soil type;

iii. indirect energy (the energy required for the manufacture of machinery and its maintenance). The operating lifetimes and depreciation periods of the machines were as described by Hülsbergen and Kalk (2001);

iv. the energy costs for transport of the beet from the farm to the sugar factory.

The sub-divisions were combined to give an overall estimate of total energy requirement per hectare, and to give an estimate of energy input per tonne of clean beet harvested. The energy content of the beet delivered to the factory gate and the output/input energy ratio per hectare were calculated.

\subsubsection{Crop protection}

The energy required to manufacture the majority of the agro-chemicals applied were not available directly, although Green (1987) provides values for 24 herbicides, 4 fungicides and 11 insecticides. The majority of energy balance studies to date use the mean values for each pesticide type. In this study, the values provided by Green (1987) for specific pesticides were assigned to their chemical group (Table 4). Where 
Table 1

The area grown, soil type, quantity of nutrients applied and adjusted yield of each sugar beet production scenario

\begin{tabular}{|c|c|c|c|c|c|c|c|c|c|c|c|c|}
\hline Scenario & $\%$ Area & Soil type & $\begin{array}{l}\text { Yield } \\
(\mathrm{t} / \mathrm{ha})^{\mathrm{a}}\end{array}$ & $\begin{array}{l}\text { Lime } \\
(\mathrm{t} / \mathrm{ha})\end{array}$ & $\begin{array}{l}\text { Organic } \\
\mathrm{N}(\mathrm{t} / \mathrm{ha})\end{array}$ & $\begin{array}{l}\text { Inorganic } \\
\mathrm{N}(\mathrm{kg} / \mathrm{ha})\end{array}$ & $\begin{array}{l}\mathrm{P}_{2} \mathrm{O}_{5} \\
(\mathrm{~kg} / \mathrm{ha})\end{array}$ & $\mathrm{K}_{2} \mathrm{O}(\mathrm{kg} / \mathrm{ha})$ & $\begin{array}{l}\mathrm{MgO} \\
(\mathrm{kg} / \mathrm{ha})\end{array}$ & $\mathrm{Na}(\mathrm{kg} / \mathrm{ha})$ & $\begin{array}{l}\mathrm{MnSO}_{3} \\
(\mathrm{~kg} / \mathrm{ha})\end{array}$ & $\begin{array}{l}\text { B spray } \\
(\mathrm{kg} / \mathrm{ha})\end{array}$ \\
\hline I & 2 & Sand & 50 & 2 & 30 FYM & 80 & - & - & - & - & - & - \\
\hline II & 2 & Sand & 50 & 2 & - & 120 & 50 & 100 & 85 & 150 & 10 & 7 \\
\hline III & 1 & Sand & 50 & 2 & - & 120 & 50 & 100 & 85 & 150 & 10 & 7 \\
\hline IV & 2 & Sand & 55 & 2 & 10 broiler & 40 & - & - & - & - & - & - \\
\hline $\mathrm{V}$ & 10 & Sand & 45 & 2 & - & 120 & 50 & 100 & 85 & 150 & - & 7 \\
\hline VI & 2 & Sand & 45 & 2 & - & 120 & 50 & 100 & 85 & 150 & - & 7 \\
\hline VII & 12 & Sandy loam & 50 & 2 & $30 \mathrm{FYM}$ & 80 & - & - & - & - & - & - \\
\hline VIII & 24 & Sandy loam & 50 & 2 & - & 120 & 50 & 100 & 85 & 150 & - & - \\
\hline IX & 21 & Clay loam & 50 & - & - & 120 & 50 & 50 & - & 150 & - & - \\
\hline $\mathrm{X}$ & 18 & Silt & 60 & - & - & 120 & 50 & 50 & - & - & - & - \\
\hline XI & 2 & Peat & 60 & - & - & 30 & 50 & 50 & 85 & - & 20 & 10 \\
\hline XII & 4 & Peat & 60 & - & - & 30 & 50 & 50 & 85 & - & 20 & 10 \\
\hline XIII (organic) & 0.2 & Sandy loam & 34 & 2 & - & - & - & 100 & - & - & - & - \\
\hline
\end{tabular}


Table 2

The timing of cultivations, mechanical weed control and irrigation for each sugar beet production scenario

\begin{tabular}{|c|c|c|c|c|c|c|c|c|c|c|c|c|c|}
\hline Operation & I & II & III & IV & $\mathrm{V}$ & VI & VII & VIII & IX & $\mathrm{X}$ & XI & XII & XIII \\
\hline \multirow[t]{2}{*}{ Stubble cultivation } & $15 \mathrm{Sep}$ & $15 \mathrm{Sep}$ & $15 \mathrm{Sep}$ & $15 \mathrm{Sep}$ & $15 \mathrm{Sep}$ & $15 \mathrm{Sep}$ & $15 \mathrm{Sep}$ & $15 \mathrm{Sep}$ & $15 \mathrm{Sep}$ & $15 \mathrm{Sep}$ & $15 \mathrm{Sep}$ & $15 \mathrm{Sep}$ & 15 Sep \\
\hline & - & - & - & - & - & - & - & - & - & - & - & - & $30 \mathrm{Sep}$ \\
\hline Subsoil (35 cm) & $15 \mathrm{Sep}$ & 15 Sep & 15 Sep & $15 \mathrm{Sep}$ & $15 \mathrm{Sep}$ & $15 \mathrm{Sep}$ & $15 \mathrm{Sep}$ & $15 \mathrm{Sep}$ & - & - & - & - & 15 Sep \\
\hline $\begin{array}{l}\text { Plough and press } \\
\qquad(25 \mathrm{~cm})\end{array}$ & 15 Feb & $15 \mathrm{Feb}$ & $15 \mathrm{Feb}$ & $15 \mathrm{Feb}$ & $15 \mathrm{Feb}$ & - & $15 \mathrm{Nov}$ & $15 \mathrm{Nov}$ & $01 \mathrm{Nov}$ & $01 \mathrm{Nov}$ & 15 Dec & 15 Dec & 15 Nov \\
\hline $\begin{array}{l}\text { Tine cultivate } \\
(10 \mathrm{~cm})\end{array}$ & - & - & - & - & - & 13 Mar & - & - & - & - & - & - & 13 Mar \\
\hline \multirow{2}{*}{$\begin{array}{l}\text { Seedbed cultivation } \\
\qquad(5 \mathrm{~cm})\end{array}$} & - & - & $20 \mathrm{Feb}$ & $20 \mathrm{Feb}$ & $15 \mathrm{Feb}$ & - & 15 Mar & 15 Mar & $01 \mathrm{Apr}$ & $01 \mathrm{Apr}$ & $24 \mathrm{Feb}$ & $01 \mathrm{Apr}$ & $01 \mathrm{Apr}$ \\
\hline & - & - & - & - & - & - & - & - & $01 \mathrm{Apr}$ & $01 \mathrm{Apr}$ & - & - & 15 Apr \\
\hline \multirow[t]{4}{*}{ Tractor hoe } & 30 May & 30 May & - & 30 May & 30 May & 30 May & 30 May & 30 May & 30 May & 30 May & - & - & 01 May \\
\hline & - & - & - & - & - & - & - & - & - & - & - & - & 10 May \\
\hline & - & - & - & - & - & - & - & - & - & - & - & - & 25 May \\
\hline & - & - & - & - & - & - & - & - & - & - & - & - & 05 Jun \\
\hline \multirow[t]{2}{*}{ Cross harrow } & - & - & - & - & - & - & - & - & - & - & - & - & 20 May \\
\hline & - & - & - & - & - & - & - & - & - & - & - & - & 05 Jun \\
\hline Mow & - & - & - & - & - & - & - & - & - & - & - & - & 02 Aug \\
\hline \multirow[t]{2}{*}{ Irrigate $(25 \mathrm{~mm} / \mathrm{ha})$} & $15 \mathrm{Jul}$ & $15 \mathrm{Jul}$ & $15 \mathrm{Jul}$ & $15 \mathrm{Jul}$ & - & - & - & - & - & - & - & - & - \\
\hline & $30 \mathrm{Jul}$ & $30 \mathrm{Jul}$ & $30 \mathrm{Jul}$ & $30 \mathrm{Jul}$ & - & - & - & - & - & - & - & - & - \\
\hline
\end{tabular}


Table 3

The pesticide treatments and application dates for each sugar beet production scenario

\begin{tabular}{|c|c|c|c|c|c|c|c|c|c|c|c|c|c|}
\hline Pesticide & $\mathrm{I}$ & II & III & IV & $\mathrm{V}$ & VI & VII & VIII & IX & $\mathrm{X}$ & $\mathrm{XI}$ & XII & XIII \\
\hline Betanal Flo (2.5 l/ha) & - & - & - & - & - & - & - & - & - & - & $14 \mathrm{Apr}$ & - & - \\
\hline Betanal Tandem (3 1/ha) & - & - & - & - & - & - & - & - & - & - & 03 Jun & 04 Jun & - \\
\hline Dow shield $(0.5$ 1/ha $)$ & - & - & - & - & - & - & - & - & - & 22 May & - & - & - \\
\hline Fusilade $(0.5$ 1/ha) & - & - & $24 \mathrm{Apr}$ & - & - & - & - & - & - & - & 06 May & - & - \\
\hline Gaucho (0.099 kg/ha) & - & - & - & - & - & - & 17 Mar & 17 Mar & 17 Mar & 17 Mar & 17 Mar & 17 Mar & - \\
\hline PDQ (3 1/ha) & - & - & - & - & - & - & - & - & - & - & - & $03 \mathrm{Apr}$ & - \\
\hline Punch C (0.625 1/ha) & 06 Aug & 06 Aug & 06 Aug & 06 Aug & 06 Aug & 06 Aug & 06 Aug & 06 Aug & 06 Aug & 06 Aug & 06 Aug & 06 Aug & - \\
\hline Pyramin DF & - & - & $15 \mathrm{Mar}^{1}$ & - & - & - & $18 \mathrm{Mar}^{2}$ & $18 \mathrm{Mar}^{2}$ & $10 \mathrm{Apr}^{3}$ & $10 \mathrm{Apr}^{3}$ & - & - & - \\
\hline Sting Eco (3 1/ha) & 17 Mar & $17 \mathrm{Mar}$ & $01 \mathrm{Feb}$ & 17 Mar & $17 \mathrm{Mar}$ & $17 \mathrm{Mar}$ & $01 \mathrm{Nov}$ & 01 Nov & - & - & - & - & - \\
\hline Temik (10 kg/ha) & 15 Mar & $15 \mathrm{Mar}$ & 15 Mar & 15 Mar & $15 \mathrm{Mar}$ & 15 Mar & - & - & - & - & - & - & - \\
\hline Thiovit (10 kg/ha) & - & - & - & - & - & - & - & - & - & - & - & - & 06 Aug \\
\hline 1: $\mathrm{GWG}^{2}+\mathrm{BF}^{1}$ & - & - & - & - & - & - & - & $09 \mathrm{Apr}$ & $23 \mathrm{Apr}$ & $23 \mathrm{Apr}$ & - & $14 \mathrm{Apr}$ & - \\
\hline 2: $\mathrm{BP}+\mathrm{VF}+$ oil & - & - & - & $21 \mathrm{Apr}$ & $21 \mathrm{Apr}$ & $21 \mathrm{Apr}$ & $23 \mathrm{Apr}$ & $23 \mathrm{Apr}$ & 08 May & 08 May & - & - & - \\
\hline 3: $\mathrm{BF}^{2}+\mathrm{Vz}$ & $06 \mathrm{Apr}$ & $06 \mathrm{Apr}$ & $06 \mathrm{Apr}$ & $06 \mathrm{Apr}$ & $06 \mathrm{Apr}$ & $06 \mathrm{Apr}$ & 09 Apr & - & - & - & - & - & - \\
\hline 4: $\mathrm{BF}^{1}+\mathrm{Vz}+\mathrm{Db}+$ oil $+\mathrm{Cl}$ & - & - & - & - & - & - & - & - & - & - & 25 May & 25 May & - \\
\hline 5: $\mathrm{BF}^{2}+\mathrm{GWG}^{2}+$ oil $+\mathrm{Cl}$ & - & - & - & - & - & - & - & - & - & - & $24 \mathrm{Apr}$ & $24 \mathrm{Apr}$ & - \\
\hline 6: $\mathrm{BT}+\mathrm{GWG}^{1}+$ oil & - & - & - & 05 May & 05 May & - & - & - & - & - & - & - & - \\
\hline 7: $\mathrm{BP}+\mathrm{Db}+\mathrm{VF}+$ oil $+\mathrm{Cl}$ & $21 \mathrm{Apr}$ & $21 \mathrm{Apr}$ & $21 \mathrm{Apr}$ & - & - & 05 May & - & - & - & - & 03 May & 04 May & - \\
\hline 8: $\mathrm{BT}+\mathrm{GWG}^{1}+$ oil $+\mathrm{Cl}$ & 05 May & 05 May & 05 May & - & - & - & - & - & - & - & - & - & - \\
\hline
\end{tabular}

Numbers $1-8$ refer to mixes.

BF: Betanal Flo ${ }^{1} 1.5$ 1/ha ${ }^{2} 1.7$ 1/ha; BP: Betanal Progress 0.75 1/ha; BT: Betanal Tandem 3 1/ha; Cl: clopyralid 0.51/ha; Db: Debut 30.0 g/ha; GWG: Goltix WG ${ }^{1} 1$ kg/ha ${ }^{2} 1.25$ kg/ha ${ }^{3} 1.7 \mathrm{~kg} / \mathrm{ha}$; oil, 1.0 1/ha; Pyramin DF ${ }^{1} 1.7 \mathrm{~kg} / \mathrm{ha}^{2} 2.5 \mathrm{~kg} / \mathrm{ha}{ }^{3} 3.3 \mathrm{~kg} / \mathrm{ha}$; VF: Venzar Flo 0.4 1/ha; Vz: Venzar 0.4 1/ha. 
Table 4

Energy (MJ/kg) required for the manufacture of pesticides (based on values from Green, 1987)

\begin{tabular}{lll}
\hline Product & Group & Energy $(\mathrm{MJ} / \mathrm{kg})$ \\
\hline Aldicarb & Carbamate & 207 \\
Carbendazim & Benzidimazole & 397 \\
Chloridazon & Pyridazinone & $264^{\mathrm{a}}$ \\
Clopyralid & Picolinic & $264^{\mathrm{a}}$ \\
Desmedipham & Carbamate & 207 \\
Diquat & Bipyridylium & 400 \\
Ethofumesate & Benzofuran & $264^{\mathrm{a}}$ \\
Flusilazole & Triazole & $168^{\mathrm{b}}$ \\
Fluazifop-p-butyl & Fop & 518 \\
Glyphosate & Phosphonic & 454 \\
Hymexazol & Isoxazole & $168^{\mathrm{b}}$ \\
Imidacloprid & Nitroimidazolidinimime & $214^{\mathrm{c}}$ \\
Lenacil & Uracil & $264^{\mathrm{a}}$ \\
Metamitron & Triazinone & 196 \\
Paraquat & Bipyridylium & 460 \\
Phenmedipham & Carbamate & 207 \\
Sulphur & & 4.6 \\
Thiram & Thio-carbamate & 207 \\
Triflusulfuron & Sulfonyl urea & 365 \\
\hline
\end{tabular}

Mineral oil was assigned a value of 38.7 MJ/1 (Dawson, 1978).

a Mean value of 24 herbicides.

${ }^{\mathrm{b}}$ Mean value of four fungicides.

${ }^{c}$ Mean value of 11 insecticides.

there was more than one value for a group, the mean was taken. Those pesticides that did not belong to one of the chemical groups in Green's study were assigned the mean value of each pesticide type (herbicide, fungicide or insecticide). An additional $23 \mathrm{MJ} / \mathrm{kg}$ was added to each value to account for storage and transport to the farm (Hülsbergen and Kalk, 2001). The energy requirement to manufacture each pesticide application is given in Table 5 .

Spray application of agro-chemicals was estimated to require 1.7 1/ha of diesel with an additional $29 \mathrm{MJ} / \mathrm{ha}$ of indirect energy (Hülsbergen and Kalk, 2001). Diesel consumption releases 39.6 MJ/1 (Reinhardt, 1993; cited Hülsbergen and Kalk, 2001).

\subsubsection{Cultivations}

The energy consumed while ploughing and sub-soiling on various soil types was derived from the regression equations described in Kalk and Hülsbergen (1999).

For those scenarios that used a press behind the plough, 20\% was added to the calculated energy requirement (Table 6). For all other cultivations (Table 6), it was assumed that the implement was pulled by a $100-\mathrm{kW}$ turbo-cooled diesel tractor at $10 \mathrm{~km} / \mathrm{h}$. The energy required for each operation was calculated using the method described by Hunt (1995). Indirect energy values were assumed as $152 \mathrm{MJ} / \mathrm{ha}$ for stubble cultivation and $143 \mathrm{MJ} / \mathrm{ha}$ for ploughing (Hülsbergen and Kalk, 2001) and all other tillage operations. 
Table 5

The energy $(\mathrm{MJ})$ required for each pesticide application

\begin{tabular}{|c|c|c|}
\hline Pesticide & Rate & Energy $(\mathrm{MJ})^{c}$ \\
\hline Agrichem Flowable Thiram (thiram) & $0.0083 \mathrm{~kg} / \mathrm{ha}$ & 2 \\
\hline Betanal Tandem (ethofumesate/phenmedipham) & $3.0 \mathrm{l} / \mathrm{ha}$ & 141 \\
\hline Dow Shield (clopyralid) & $0.5 \mathrm{l} / \mathrm{ha}$ & 29 \\
\hline Fusilade (fluazifop- $p$-buty) & $0.5 \mathrm{l} / \mathrm{ha}+1 \mathrm{l} / \mathrm{ha}$ oil & $68+39$ \\
\hline Gaucho (imidacloprid $70 \% \mathrm{w} / \mathrm{w}$ ) & $0.099 \mathrm{~kg} / \mathrm{ha}$ & 16 \\
\hline PDQ (diquat/paraquat) & $3.0 \mathrm{l} / \mathrm{ha}$ & 275 \\
\hline Punch C (carbendazim/flusilazole) & $0.625 \mathrm{l} / \mathrm{ha}$ & 63 \\
\hline Pyramin DF (chloridazon $65 \% \mathrm{w} / \mathrm{w}$ ) & $1.7 \mathrm{~kg} / \mathrm{ha}$ & 317 \\
\hline Pyramin DF (chloridazon $65 \% \mathrm{w} / \mathrm{w}$ ) & $2.5 \mathrm{~kg} / \mathrm{ha}$ & 466 \\
\hline Pyramin DF (chloridazon $65 \% \mathrm{w} / \mathrm{w}$ ) & $3.3 \mathrm{~kg} / \mathrm{ha}$ & 616 \\
\hline Sting Eco (glyphosate) & $3.01 /$ ha & 172 \\
\hline Tachigaren (hymexazol) & $0.015 \mathrm{~kg} / \mathrm{ha}$ & 3 \\
\hline Temik (aldicarb 10\% w/w) & $10.0 \mathrm{~kg} / \mathrm{ha}$ & 230 \\
\hline Thiovit (sulphur $80 \% \mathrm{w} / \mathrm{w}$ ) & $10.0 \mathrm{~kg} / \mathrm{ha}$ & 37 \\
\hline Mix 1 & See Table 3 & 293 \\
\hline Mix 2 & See Table 3 & 145 \\
\hline Mix 3 & See Table 3 & 113 \\
\hline Mix 4 & See Table 3 & 140 \\
\hline Mix 5 & See Table 3 & 140 \\
\hline Mix 6 & See Table 3 & 333 \\
\hline Mix 7 & See Table 3 & 174 \\
\hline Mix 8 & See Table 3 & 362 \\
\hline Mix 9 & See Table 3 & 328 \\
\hline
\end{tabular}

${ }^{a}$ Including $23 \mathrm{MJ} / \mathrm{kg}$ active ingredient for storage and transport (except sulphur).

\subsubsection{Nutrition}

The chemical composition of fertiliser products are given in Table 7 in addition to the energy values for their manufacture. The most modern ammonium nitrate fertiliser manufacturing factories have an accumulated production cost of $30.5 \mathrm{MJ} / \mathrm{kg} \mathrm{N}$ (Jenssen and Kongshaug, 2003). However, the present day 'average Europe' value incorporates the production costs of older plants to give an accumulated production cost of $38.7 \mathrm{MJ} / \mathrm{kg} \mathrm{N}$ (Jenssen and Kongshaug, 2003): this is the value assumed here. An additional $1.3 \mathrm{MJ} / \mathrm{kg}$ accounts for packaging and transport (Kaltschmidt and Reinhardt, 1997). Farmyard and broiler manures were assumed to be by-products whose production incurred no energy cost. Data for calcined magnesite, manganese sulphate, boron spray and agricultural salt were not available so an estimate was based on the extraction of raw material (Jenssen and Kongshaug, 2003), packaging and transport (Kaltschmidt and Reinhardt, 1997) and processing.

The diesel consumption ( $1 /$ ha) for the application of fertiliser products were derived from regression equations described in Kalk and Hülsbergen (1999). For the simultaneous application of fertiliser products the weights were totalled for use in the regression equation, with an additional $28 \mathrm{MJ} /$ ha indirect energy (Hülsbergen and Kalk, 2001). The application of $30 \mathrm{t} / \mathrm{ha}$ farmyard manure required $16.6 \mathrm{l} / \mathrm{ha}$ and $813 \mathrm{MJ} / \mathrm{ha}$ indirect energy (Hülsbergen and Kalk, 2001). The loading and transport of livestock manures were assigned energy values of $0.51 / t$ (Daalgard, 2001) and 
Table 6

Energy input for cultivations $(\mathrm{MJ} / \mathrm{ha})$ in relation to soil type

\begin{tabular}{ll}
\hline Operation & Energy $(\mathrm{MJ} / \mathrm{ha})$ \\
\hline Plough $(23 \mathrm{~cm})$ & $624-1160^{\mathrm{a}}$ \\
Plough and press & $749-1392^{\mathrm{a}}$ \\
Stubble cultivation & 166 \\
Spring cultivations (light soils) & 138 \\
Spring cultivations (heavy soils) & $330^{\mathrm{b}}$ \\
Subsoil $(35 \mathrm{~cm})$ & $1061-1560^{\mathrm{a}}$ \\
Rotary hoe & 95 \\
Mow & 139
\end{tabular}

The plough and sub-soil values are derived from regression equations from Kalk and Hülsbergen (1999) with the press assumed as $20 \%$ of the plough value. All other values are derived from Hunt (1995).

a The range of values assumed for the ploughing of sand, peat, sandy loam, clay loam and silt soils or the subsoiling of sand and sandy loam soils.

${ }^{\mathrm{b}}$ It is assumed that two passes of a field cultivator are required to create a seedbed on heavy soil.

Table 7

Chemical composition of fertiliser products and energy values for their manufacture (including packaging and transport)

\begin{tabular}{lll}
\hline Product & Composition & Energy for manufacture \\
\hline Ammonium nitrate (average Europe) & $34.5 \% \mathrm{~N}$ & $38.7^{\mathrm{a}} \mathrm{MJ} / \mathrm{kg} \mathrm{N}$ (Jenssen and \\
& & $\mathrm{Kongshaug}, 2003)$ \\
Triple superphosphate & $48 \% \mathrm{P}_{2} \mathrm{O}_{5}\left(\mathrm{P}_{2} \mathrm{O}_{5}: 43.6 \% \mathrm{P}\right)$ & $12.0 \mathrm{MJ} / \mathrm{kg} \mathrm{P}$ (Daalgard, 2001) \\
Muriate of potash & $60 \% \mathrm{~K}_{2} \mathrm{O}\left(\mathrm{K}_{2} \mathrm{O}: 83 \% \mathrm{~K}\right)$ & $7.0 \mathrm{MJ} / \mathrm{kg} \mathrm{K}$ (Daalgard, 2001) \\
Sylvinite & $24 \% \mathrm{~K}_{2} \mathrm{O}\left(\mathrm{K}_{2} \mathrm{O}: 83 \% \mathrm{~K}\right)$ & $7.0 \mathrm{MJ} / \mathrm{kg} \mathrm{K}$ (Daalgard, 2001) \\
Lime & & $0.03^{\mathrm{a}} \mathrm{MJ} / \mathrm{kg}$ (Refsgaard et al., 1998) \\
Calcined magnesite & $80 \% \mathrm{MgO}$ & $8.75^{\mathrm{b}} \mathrm{MJ} / \mathrm{kg} \mathrm{MgO}$ \\
Boron spray & & $5.0^{\mathrm{c}} \mathrm{MJ} / \mathrm{kg}$ product \\
Salt & & $2.5^{\mathrm{c}} \mathrm{MJ} / \mathrm{kg}$ product \\
Manganese sulphate & $2.5^{\mathrm{c}} \mathrm{MJ} / \mathrm{kg}$ product \\
\hline
\end{tabular}

${ }^{a}$ Excludes packaging and transport for which an additional $1.3 \mathrm{MJ} / \mathrm{kg}$ is added (Kaltschmidt and Reinhardt, 1997).

${ }^{\mathrm{b}}$ Based on mineral extraction values of $0.8 \mathrm{MJ} / \mathrm{kg}$ (Jenssen and Kongshaug, 2003), transport of $1.3 \mathrm{MJ} /$ $\mathrm{kg}$ (Kaltschmidt and Reinhardt, 1997) plus an additional estimate for the calcining of raw magnesite in a furnace.

${ }^{\mathrm{c}}$ Based on mineral extraction values of $0.8 \mathrm{MJ} / \mathrm{kg}$ (Jenssen and Kongshaug, 2003), transport of $1.3 \mathrm{MJ} /$ $\mathrm{kg}$ (Kaltschmidt and Reinhardt, 1997) plus an additional estimate for product processing.

$0.21 / \mathrm{t} / \mathrm{km}$ (Daalgard, 2001), respectively. There are no data for manure transport distances to beet fields, but we have assumed an average of $10 \mathrm{~km}$; in all probability this is an overestimate.

\subsubsection{Crop culture and delivery}

The energy values associated with the culture of the crop are given in Table 8. The indirect energy for the harvest of beet was $1074 \mathrm{MJ} / \mathrm{ha}$ (Hülsbergen and Kalk, 2001). The indirect energy values for drilling, irrigation and transport to the clamp were estimated at 75, 29 and $28 \mathrm{MJ} /$ ha, respectively. Those for cleaning and loading were estimated at $100 \mathrm{MJ} / \mathrm{ha}$. 
Table 8

Energy values (MJ) or fuel consumption (litres of diesel) required for crop culture operations

\begin{tabular}{lc}
\hline & Energy value/fuel consumption \\
\hline Beet seed & $250.0 \mathrm{MJ} / \mathrm{unit}$ (Stephan, 1997) \\
Cover crop seed (spring barley) & $5.5 \mathrm{MJ} / \mathrm{kg}$ (Kalk et al., 1995) \\
Drill & $240.0 \mathrm{MJ} / \mathrm{ha}$ (Green, 1987) \\
Irrigation & $52.0 \mathrm{MJ} / \mathrm{mm} / \mathrm{ha}$ (Daalgard, 2001) \\
Harvest & $47.0 \mathrm{l} / \mathrm{ha}(\mathrm{K}$. Jaggard pers comm. $)$ \\
Transport to clamp $(2 \mathrm{~km})$ & $0.2 \mathrm{l} / \mathrm{t} / \mathrm{km}$ (Daalgard, 2001) \\
Clean and load & $0.5 \mathrm{l} / \mathrm{t}$ (Daalgard, 2001) \\
\hline
\end{tabular}

The average distance for each tonne of beet from the farm to the factory was 46 $\mathrm{km}$ in 2002. We assumed the transport used a 38-t gross weight truck with an energy requirement of $0.0161 / \mathrm{t} / \mathrm{km}$ (Küsters, 1999). The return journey assumed the empty truck weighed $12 \mathrm{t}$ and, for example, a 50-t/ha yield would require $2.1 \mathrm{loads} / \mathrm{ha}$ of empty journeys at $0.016 \mathrm{1} / \mathrm{t} / \mathrm{km}$. The average distance to transport organic beet was estimated as $144 \mathrm{~km}$ (K. Jaggard pers comm.).

\subsubsection{Global warming potential}

Atmospheric emissions from each source of fuel and their GWP, expressed as tonnes of $\mathrm{CO}_{2}$ equivalent are given in Table 9. The proportion of each fuel source used in manufacture, field operations and indirect energy are given Table 10.

Table 9

Gaseous emissions $(\mathrm{kg})$ from fuel sources and their global warming potential (GWP) (from Houghton, 1996)

\begin{tabular}{llll}
\hline Fuel source & $\mathrm{CO}_{2}$ & $\mathrm{~N}_{2} \mathrm{O}$ & $\mathrm{CH}_{4}$ \\
\hline Electricity $(\mathrm{kWh})$ & 0.0612 & $0.882^{-6}$ & $2.77^{-6}$ \\
Natural gas $(\mathrm{kWh})$ & 0.209 & $2.59^{-6}$ & $22.0^{-6}$ \\
Diesel (l) & 2.73 & $18.1^{-6}$ & $173.0^{-6}$ \\
Fuel oil (l) & 3.16 & $24.7^{-6}$ & $57.7^{-6}$ \\
Naptha (l) & 3.42 & 0 & $113.0^{-6}$ \\
GWP $\mathrm{CO}_{2}$ equivalence factor & 1 & 310 & 21 \\
\hline
\end{tabular}

Table 10

Proportion of fuel source (\%) for product manufacture, field operations and indirect energy (from Green, 1987)

\begin{tabular}{lccccc}
\hline Operation & Electricity $^{\mathrm{a}}$ & Natural gas & Diesel & Fuel oil & Naptha \\
\hline N fertiliser manufacture & 5 & 95 & 0 & 0 & 0 \\
PK fertiliser manufacture & 0 & 0 & 0 & 100 & 0 \\
Pesticide manufacture & 40 & 22 & 0 & 5 & 33 \\
Transport & 0 & 0 & 100 & 0 & 0 \\
Field operations & 0 & 0 & 100 & 0 & 0 \\
Irrigation & 30 & 0 & 70 & 0 & 0 \\
Indirect & 70 & 0 & 30 & 0 & 0
\end{tabular}

\footnotetext{
${ }^{a}$ Assumes generated by fuel sources in the following proportions: coal $34 \%$, oil $2 \%$, natural gas $32 \%$, nuclear and other renewable sources 32\% (Eurostat, 1998).
} 


\section{Results}

\subsection{Crop protection}

With the exception of the organic crop, most of the crop protection interventions involved the use of pesticides. The energy content of each application is listed in Table 5. Scenarios that used chloridazon, a herbicide especially useful on heavy soils but that requires large application rates, had large crop protection energy costs. Aldicarb, used for nematode and aphid control on sand soils, also represents a large energy consumption (aldicarb will not be used after 2004, but its role will tend to be taken by other nematicides applied at similar doses). The overall energy requirement for crop protection tended to be lowest in those crops grown on sand soils and was greatest on the more nutrient rich soils, especially the peat soils (Table 11) that require several herbicide applications to control the many weed flushes. The use of mechanical weed control within the organic system resulted in a greater energy cost than the conventional crops grown on the same soil that used herbicides.

\subsection{Nutrition}

The smallest energy requirement for crop nutrition were in the conventional scenarios on peat soil and the organic scenario on sandy loam (Table 11). The application of lime provides a suitable $\mathrm{pH}$ for several successive crops but in the rotation, it is often applied to beet, the most acid-sensitive of the common arable species. Similarly, in an organic rotation, sylvinite may be applied if it is necessary to maintain soil fertility but nutrients from this application will support several subsequent crops. Many peat, silt and clay loam soils contain sufficient potash such that only a maintenance dressing is required thus the energy input for this nutrient was small and lime was not required. Peat and silt soils usually contain sufficient sodium that none need

Table 11

The energy input (GJ/ha) for crop protection, nutrition, cultivation, crop culture and off farm transport for each sugar beet production scenario

\begin{tabular}{llllll}
\hline Scenario & Crop protection & Nutrition & Cultivation & Crop culture & Off farm transport \\
\hline I & 1.8 & 10.7 & 2.6 & 8.2 & 2.1 \\
II & 1.8 & 10.8 & 2.6 & 8.2 & 2.2 \\
III & 2.3 & 10.8 & 2.7 & 8.8 & 2.2 \\
IV & 1.8 & 6.6 & 2.9 & 8.4 & 2.4 \\
V & 1.8 & 10.7 & 2.6 & 5.3 & 1.9 \\
VI & 1.8 & 10.7 & 1.6 & 5.3 & 1.9 \\
VII & 1.8 & 10.7 & 3.6 & 5.5 & 2.2 \\
VIII & 2.0 & 10.6 & 3.7 & 5.5 & 2.2 \\
IX & 2.2 & 6.7 & 2.6 & 5.5 & 2.2 \\
X & 2.3 & 5.7 & 2.6 & 5.9 & 2.6 \\
XI & 2.3 & 3.1 & 1.5 & 6.5 & 2.6 \\
XII & 2.6 & 3.1 & 1.5 & 5.9 & 2.6 \\
XIII & 2.0 & 3.5 & 3.9 & 5.0 & 4.5 \\
\hline
\end{tabular}


be applied, while peat soils mineralize large quantities of nitrogen so that only a small application of this nutrient is necessary. The crops grown on clay loam and silt soil had energy inputs for nutrition of approximately 4000 and $5000 \mathrm{MJ} /$ ha lower than that on sand or sandy loam soil with much of the difference attributed to differences in the need for nitrogen fertiliser. The manufacture of mineral fertiliser, not including lime and its transport, accounted for about $7400 \mathrm{MJ} / \mathrm{ha}$ when applied to crops grown on sand or sandy loam, with between 306 and $364 \mathrm{MJ} /$ ha for field operations. If $30 \mathrm{t} / \mathrm{ha}$ of farmyard manure is applied, about 2400 and $600 \mathrm{MJ} / \mathrm{ha}$ are required for loading and transport, respectively, with $660 \mathrm{MJ} /$ ha for application. Broiler manure was applied at one third of the rate of farmyard manure and the associated energy costs for its transport and application were also approximately one third.

\subsection{Cultivation}

The scenarios with the lowest energy requirement for cultivation had fewer deep tillage operations (ploughing and/or sub-soiling), or were on lighter soils (sand or peat) (Table 11). The scenarios on the clay loam and silt soils were not sub-soiled although ploughing alone incurred a greater energy cost than for the other soil types. The conventional scenarios on sandy loam and the organic scenario had large energy requirements for cultivation: both of the conventional scenarios were sub-soiled and ploughed while the organic scenario had an additional tine cultivation to control weeds prior to sowing. We have assumed that all of the sand and sandy loam soils were subsoiled at an energy requirement of 1060 and $1560 \mathrm{MJ} / \mathrm{ha}$, respectively, although in reality, many of these soils are not subsoiled before every beet crop.

\subsection{Crop culture}

The energy used in crop culture is greatly increased by the use of irrigation, an additional $2.6 \mathrm{GJ} / \mathrm{ha}$, while the growing and removal of a barley cover crop required $590 \mathrm{MJ} / \mathrm{ha}$.

\subsection{Total energy input per tonne of clean beet harvested}

The total energy inputs per tonne of clean beet harvested are shown in Figs. 1 and 2. The higher yields and lower energy inputs into scenarios X-XII resulted in the least energy input per tonne of beet to the farm gate with values of 274,223 , and $216 \mathrm{MJ} / \mathrm{t}$, respectively. Of the scenarios on sand soil, scenario IV required the least energy input $(356 \mathrm{MJ} / \mathrm{t})$ on account of a lower energy input for nutrition and a higher yield. Of the scenarios on sand that applied mineral fertiliser, the minimum tilled crop (scenario VI) required the least input per tonne $(430 \mathrm{MJ} / \mathrm{t}$ ) despite its lower yield on account of no irrigation and lower cultivation costs. Scenario III required the greatest energy input (492 MJ/t) owing to higher energy inputs for nutrition, crop protection and culture compared to scenarios I and II, despite yielding the same. Although the organic crop had a low energy input per unit area, the low yield 


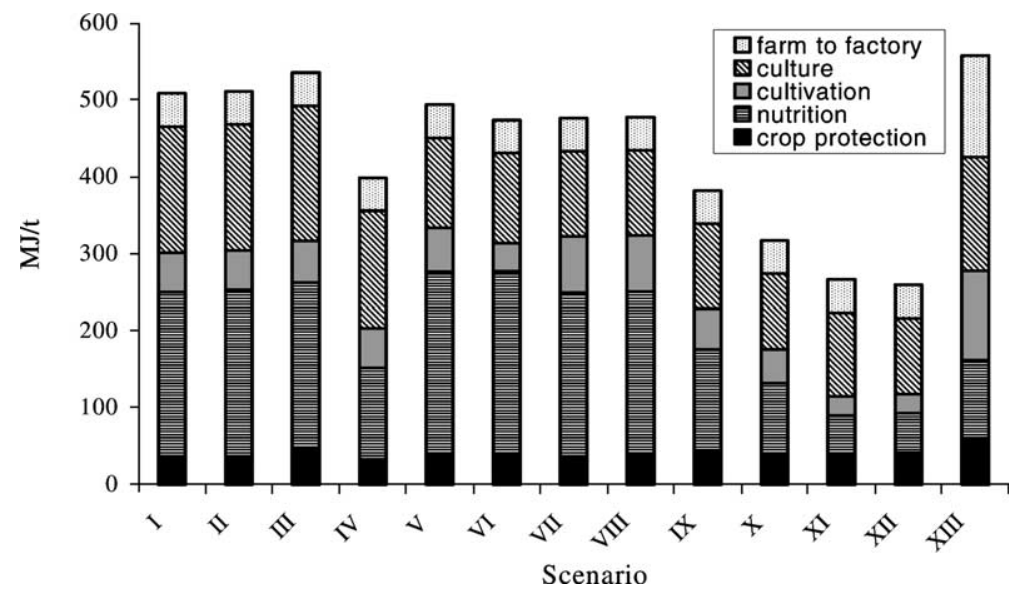

Fig. 1. Total energy input per adjusted tonne of clean beet harvested in each scenario, categorised by crop protection, nutrition, cultivation and crop culture.

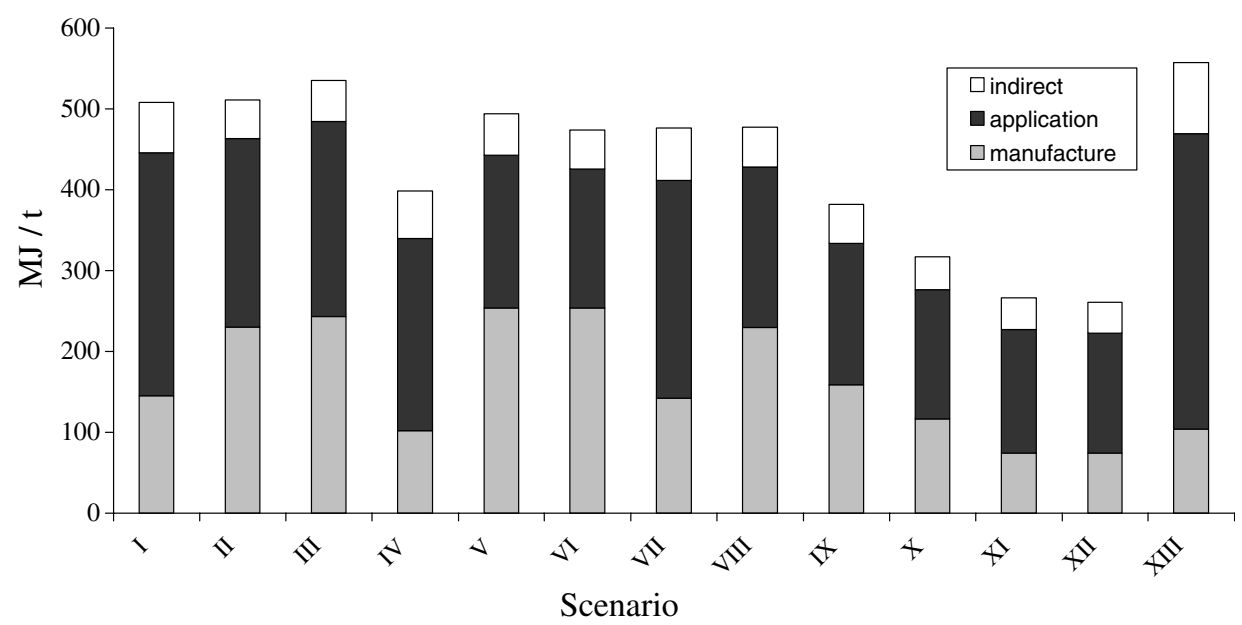

Fig. 2. Total energy input per adjusted tonne of clean beet harvested in each scenario, categorised by manufacture, application and indirect.

(34 t/ha) resulted in the energy input at the farm gate being $425 \mathrm{MJ} / \mathrm{t}$, slightly less than the conventional scenarios on sandy loam that were 433 and $435 \mathrm{MJ} / \mathrm{t}$. In the UK, there is one factory located in Newark that processes organic beet. Organic beet therefore has to be taken to this location irrespective of where it is grown within the UK, unlike conventional beet that will be processed in the factory nearest to where it is produced. The greater average distance to transport organic beet to the Newark factory compared to the conventional scenarios increased the energy requirement to $557 \mathrm{MJ} / \mathrm{t}$, a value greater than any conventionally produced crops. 
Table 12

The energy efficiency for each scenario described as the ratio between energy output $(\mathrm{GJ} / \mathrm{ha})$ and energy input (GJ/ha) and global warming potential (GWP)/ha expressed as equivalent tonnes of carbon dioxide

\begin{tabular}{lllllll}
\hline Scenario & $\begin{array}{l}\text { Energy output } \\
(\mathrm{GJ} / \mathrm{ha})\end{array}$ & $\begin{array}{l}\text { Energy input } \\
(\mathrm{GJ} / \mathrm{ha})\end{array}$ & $\begin{array}{l}\text { Output/input } \\
\text { ratio }\end{array}$ & $\begin{array}{l}\mathrm{GWP} \\
\left.\text { (eq. } \mathrm{CO}_{2}\right) / \text { ha }\end{array}$ & $\begin{array}{l}\mathrm{GWP} \\
\left.\text { (eq. t } \mathrm{CO}_{2}\right) / \mathrm{t} \\
\text { clean beet }\end{array}$ & $\begin{array}{l}\mathrm{GWP} \\
\left.\text { (eq. t } \mathrm{CO}_{2}\right) / \mathrm{GJ} \\
\text { output }\end{array}$ \\
\hline I & 195.0 & 25.41 & 7.67 & 1.5 & 0.03 & 0.00769 \\
II & 195.0 & 25.55 & 7.63 & 1.47 & 0.029 & 0.00754 \\
III & 195.0 & 26.76 & 7.29 & 1.54 & 0.031 & 0.00790 \\
IV & 214.5 & 21.92 & 9.78 & 1.26 & 0.023 & 0.00587 \\
V & 175.5 & 22.22 & 7.90 & 1.28 & 0.028 & 0.00729 \\
VI & 175.5 & 21.32 & 8.23 & 1.22 & 0.027 & 0.00695 \\
VII & 195.0 & 23.81 & 8.18 & 1.42 & 0.028 & 0.00728 \\
VIII & 195.0 & 23.88 & 8.16 & 1.38 & 0.028 & 0.00708 \\
IX & 195.0 & 19.10 & 10.21 & 1.09 & 0.022 & 0.00559 \\
X & 234.0 & 19.02 & 12.30 & 1.1 & 0.018 & 0.00470 \\
XI & 234.0 & 15.97 & 14.65 & 0.93 & 0.016 & 0.00397 \\
XII & 234.0 & 15.64 & 14.96 & 0.91 & 0.015 & 0.00389 \\
XIII & 132.6 & 18.95 & 7.00 & 1.16 & 0.034 & 0.00875 \\
\hline
\end{tabular}

\subsection{Energy input and output}

One tonne of dry beet contains 16.9 GJ of energy (Austin et al., 1978) while the harvested beet product contains $23 \%$ dry matter. The energy output for each scenario was calculated thus:

Energy output/ha $=16.9 * 0.23 *$ yield of clean beet/ha.

The energy output/input ratio was calculated by dividing the total energy output by the energy input.

The most energy efficient scenarios, those with a high output/input ratio, are the crops grown on peat or silt and to a lesser extent, clay loam soils (Table 12). The conventional sandy loam scenarios were generally more efficient than the crops grown on sand, with the exception of the minimum tilled scenario on sand and the scenario to which broiler manure was applied. The organic crop was the least energy efficient production scenario. The average output/input ratio for the whole of the UK, based on the proportion of crops grown under each scenario, was 9.7.

\subsection{Global warming potential}

The GWP (expressed as equivalent tonnes of carbon dioxide per hectare) for each scenario is summarised in Fig. 3 and the GWP per tonne of beet is given in Table 12. The GWP per hectare was lowest in the scenarios on peat soils, then silt and clay loam, mainly as a result of a low GWP associated with small inputs of fertiliser. The high yielding peat and silt scenarios had the lowest GWP per tonne of clean beet. The scenarios on sand that used farmyard manure or mineral fertiliser in addition to irrigation had the largest GWP per hectare. The crops that had broiler manure applied or used minimum tillage had the lowest GWP value of those crops grown 


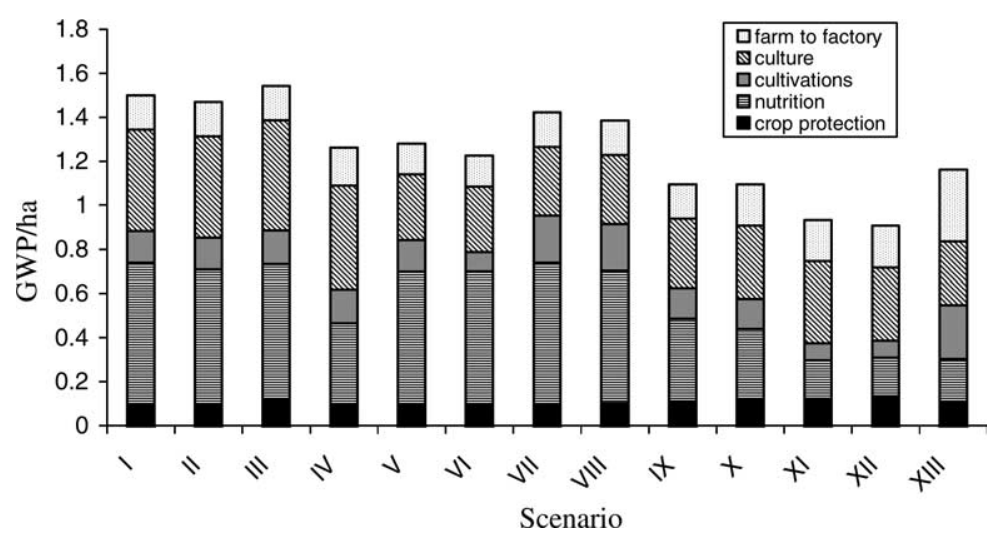

Fig. 3. Global warming potential (GWP) expressed as tonnes $\mathrm{CO}_{2}$ equivalent per hectare of beet grown.

on sand. The GWP of the organic scenario was low on farm but was increased greatly as a result of the greater distance to transport the organic beet to the factory. The low yield resulted in the greatest GWP per tonne of clean beet. The average GWP per tonne of clean beet for the whole of the UK based on the proportion of crops grown under each scenario is 0.024 eq. $\mathrm{CO}_{2} / \mathrm{t}$.

\section{Discussion}

The overall energy input for beet production in the UK ranged between 15.72 and $25.94 \mathrm{GJ} / \mathrm{ha}$, similar to the estimate of Hülsbergen and Kalk (2001) who found that sugar beet production in Germany required between 14.2 and $36.9 \mathrm{GJ} / \mathrm{ha}$ with a mean of $29.49 \mathrm{GJ} / \mathrm{ha}$. Hülsbergen and Kalk (2001) assigned a mean energy value of $6.96 \mathrm{GJ} /$ ha for the production of livestock manure which was not included in this study.

The energy input for sugar beet production was found to be largely influenced by crop nutrition that is, in turn, dictated by the soil type on which the beet crop is grown. The energy required for the manufacture of fertiliser, in particular nitrogen, or the application of large volumes of livestock manure comprised a significant portion of the energy input to crops grown on the less fertile soils. On the nutrient rich soils low nitrogen and potassium input without the need for lime or salt, in addition to a low energy requirement for seedbed cultivation, meant that despite the many post emergence herbicide treatments, the overall energy input was low while yields were high. Where livestock manure is used, much of the crop's nutrient requirements are supplied. This reduces the energy input slightly but more importantly, recycles nutrients and improves the overall sustainability of the system. We assumed that the manure was transported $10 \mathrm{~km}$ and minimising this distance is an important consideration. It is also worth noting that the industrial processes to manufacture fertiliser are becoming more energy efficient and as a consequence, the energy input for 
the manufacture of ammonium nitrate and phosphorous fertiliser will decrease in the future (Jenssen and Kongshaug, 2003). Mineral fertiliser therefore, will probably become a more energy efficient method to feed crops compared to farmyard manure unless the manure is produced near to the field where it is applied.

The use of minimum tillage on sand soil required one of the lowest inputs with respect to crop cultivation, thus minimum tillage offers potential for a reduction in energy input to beet production. A comparison of integrated and conventional production by Bailey et al. (2003) concluded the use of minimum tillage in integrated systems to be one of the key differences between the energy inputs of the two. For the UK sugar beet crop, minimum tillage does reduce the energy input but does not have the greatest influence. Bailey et al. (2003) also found however, that crop output in minimum tilled crops was reduced in certain cases as a result of increased weed populations that reduced crop yield. The viability of using such techniques must be considered on a farm specific basis. It should also be noted that many whole-rotation improvements, such as subsoiling and liming, have been included as part of the costs of the beet crop in the current study. In reality they should be associated with other crops in the rotation also.

Other key factors included the use of irrigation on sand and deep cultivations on heavier soils, such as silt and clay. Crop protection did not have as great an impact, mainly as a result of the small quantities of active ingredients required and the small quantity of energy associated with the spraying of chemicals.

It should be noted that the yield of beet in the current study is grown to optimise sugar yield and not for root yield and thus is expressed as washed and adjusted to a $16 \%$ sugar content standard. Hülsbergen and Kalk (2001) refer to the use of a 'grain equivalent' as a means of benchmarking crops based on their nutritional content as opposed to solely their calorific content in order to allow comparisons between, for example, crops grown for protein and crops grown for starch. Since the current study compares the production methods of sugar beet alone, this concept is not used here, but the yield in each scenario was adjusted to account for differences in sugar concentration.

At present, organic production accounts for $0.2 \%$ of beet in the UK. Beet grown under organic methods on sandy loam had a low requirement for crop nutrition in comparison to the conventional scenarios, but a greater requirement for transport from the farm. We are probably overstating the energy efficiency of the organic scenario because the beet crop is using nitrogen fixed earlier in the rotation. In many cases, this will be nitrogen fixed by a legume that is grown solely for this purpose and we have made no allowance for the energy demands of this legume crop. Further, the requirement for off farm transport may have been underestimated slightly since it was assumed that all beet, whatever the production system, was mixed with the same proportion of soil and trash during delivery. Harvested organic beet is almost always mixed with more weeds than conventional beet that retain more soil and are also transported to the factory. Overall, the low yield of the organic scenario resulted in an additional energy input of $103 \mathrm{MJ} / \mathrm{t}$ compared to conventional beet grown on sandy loam using mineral fertiliser. The organic scenario also had the greatest GWP/t, although this was chiefly a result of the diesel consumed in transporting the harvested crop further to the factory than the conventional scenarios. 
Many of the calculations and results in this paper rely upon the estimated yield of each scenario and we have used estimates that approximate to current mean yield values. It is our contention that this variation in yield is caused by a response to the amount of water available for growth, either as a result of differences in irrigation practice or of differences in soil type. In reality, variation in yields will occur despite adherence to the inputs specified for each scenario. Yields and thus energy output are greatly influenced by small and subtle shifts in, for example, the depth and time of seedbed cultivation and sowing, or the timing of herbicide applications. Further improvement in the energy efficiency of beet production will most likely be achieved by optimising the timing of such inputs to improve output and will be largely independent of the fossil energy input.

The UK beet crop produces between 7.3 and 15.0 times as much energy in dry matter at the sugar factory gate as consumed in its production, with an average ratio of 9.7. It has an average GWP of 0.024 eq. $\mathrm{CO}_{2}$ per tonne of clean beet harvested, equivalent to 0.0062 eq. $\mathrm{t} \mathrm{CO}_{2}$ per GJ output. The ratio for winter wheat grain has been calculated at between 6.0 and 13.0 (Keusters and Lammel, 1999), 8.9 (Richards, 2000) and 13.2 (Rathke and Diepenbrock, 2003). These ratios correspond to an estimated GWP of between 0.174 and 0.093 eq. $t \mathrm{CO}_{2}$ per tonne, equivalent to 0.0109 and 0.0053 eq. $\mathrm{CO}_{2}$ per GJ output. The output/input ratio for winter oilseed rape has been determined at 7.67 (Richards, 2000) and 8.09 (Rathke and Diepenbrock, 2003), while a ratio of 4.5 was calculated for sunflower (Kallivroussis et al., 2002). Sugar beet may be a potentially good candidate to be grown for biofuel production in north-west Europe. Consideration however, must given to the entire biofuel production chain to include product processing not covered within the scope of this study. The availability of data that compares the efficiency of beet in the UK with crops produced in other regions of the world, such as sugar cane, is sparse. Austin et al. (1978) address this matter although the production methods and the energy associated with manufacture of inputs have since altered, quite considerably in cases such as fertiliser manufacture. To allow an accurate comparison of the two crops, a further study that considers present day production methods and input values is needed to compare UK beet with a similarly detailed assessment of sugar cane production.

\section{Conclusions}

Energy use within agriculture is considered to be a key indicator of sustainable development and the use of methods to mitigate its environmental impact is vital. Crop production methods that reduce energy input while maintaining output are important components of a sustainable agricultural system. In the UK, beet production on peat, silt or clay loam soils that are more water retentive and tend to produce larger yields, is preferable as a means of optimising energy efficiency and minimising the GWP from inputs. The energy efficiency of peat soil is however in part, due to the mineralisation of large amounts of organic matter to produce nitrate and ammonia, thus eliminating the need for $\mathrm{N}$ fertiliser. In the long term this process is not sustainable 
since the peat will gradually oxidise and eventually produce only small amounts of mineral N. Beet yields are greatly dependent upon the timing of input application thus any alteration in such a timing that increases yield will also increase the energy efficiency.

The output/input energy ratio of beet grown in the UK compares favourably to other arable crops grown in Europe, although its performance compared to sugar cane produced in the southern hemisphere requires quantification. The current study has only taken account of the energy input and output to the factory gate and has not considered differences between crops that may occur during the processing of the harvested product.

One aspect of the environmental impact of the UK sugar beet crop has been considered. A more holistic approach, to include an assessment of the nitrogen cycle and ecotoxicity of pesticides on wildlife, is also required.

\section{Acknowledgement}

This work was part of an environment audit of UK beet crops funded by the British Beet Research Organisation (BBRO).

\section{References}

Austin, R.B., Kingston, G., Longden, P.C., Donovan, P.A., 1978. Gross energy yields and the support energy requirements for the production of sugar from beet and cane; a study of four production areas. Journal of Agricultural Science 91, 667-675.

Bailey, A.P., Basford, W.D., Penlington, N., Park, J.R., Keatinge, J.D.H., Rehman, T., Tranter, R.B., Yates, C.M., 2003. A comparison of energy use in conventional and integrated arable farming systems in the UK Agriculture. Ecosystems and Environment 97, 241-253.

Dalgaard, T., 2000. Farm types - how can they be used to structure, model and generalise farm data? In: Weidema, B.P., Meeusen, M.J.G. (Eds.), Agricultural Data for Life Cycle Assessments. Report 2.00.01, Agricultural Economics Research Institute, The Hague, The Netherlands, ISBN 90-5242-5639, 98-114.

Dalgaard, T., Halberg, N., Porter, R.P., 2001. A model for fossil energy use in Danish agriculture used to compare organic and conventional farming. Agriculture, Ecosystems and Environment 87, 51-65.

Dawson, S.M., 1978. Energy requirements of inputs to agriculture in New Zealand. New Zealand Energy Research and Development Committee, Report No. 41, October 1978. Joint Centre for Environmental Sciences, Lincoln College, Canterbury, New Zealand.

Department of the Environment and Rural Affairs (DEFRA)., 2003. Agriculture in the United Kingdom 2002. The Stationary Office, London, UK.

Eurostat., 1998. Electricity generated by fuel type used: an EU comparison. Eurostat Dataset ST311121.

Green, M., 1987. Energy in pesticide manufacture, distribution and use. In: Helsel, Z.R. (Ed.), Energy in Plant Nutrition and Pest Control, vol. 7. Elselvier, Amsterdam, ISBN 0-444-42753-8, pp. 165-177.

Houghton, J.T., Miera Filho, J.G., Callander, B.A., Harris, N., Kattenberg, A., Maskell, K., 1996. Climate Change 1995: The Science of Climate Change, Contribution of Working Group 1 to the Second Assessment Report of the Intergovernmental Panel on Climate Change. Cambridge University Press, Cambridge.

Hülsbergen, K.J., Kalk, W.D., 2001. Energy balances in different agricultural systems - can they be improved? The International Fertiliser Society Proceedings No. 476. 
Hunt, D., 1995. Farm Power and Machinery Management, Ninth ed. Iowa State University Press, Ames, Iowa.

Intergovernmental Panel on Climate Change (IPCC)., 1997. In: Houghton, J.T. (Ed.), Greenhouse Gas Inventory Reference Manual, vol. 3. IPCC Technical Support Unit, London.

Jenssen, T.K., Kongshaug, G., 2003. Energy consumption and greenhouse gas emissions in fertiliser production. The International Fertiliser Society Proceedings No. 509.

Kallivroussis, L., Natsis, A., Papadakis, G., 2002. The energy balance of sunflower production for biodiesel in Greece. Biosystems Engineering 81, 347-354.

Kalk, W.D., Biermann, S., Hülsbergen, K.J., 1995. Standort- und betriebsbezogene Energiebilanzen zur Charakterisierung der Landnutzungsintensität. ATB-Berichte 10/95. Institut für Agrartechnik Potsdam-Bornim, D.

Kalk, W.D., Hülsbergen, K.J., 1999. Dieselkraftstoffeinsatz in der Pflanzenproduktion. Landtechnik 54, 332-333.

Kaltschmidt, M., Reinhardt, A., 1997. Nachwachsende Energieträger. Grundlagen, Verfahren, ökologische Bilanzierung. Vieweg Verlag, Braunschweig/Wiesbaden.

Kuesters, J., Lammel, J., 1999. Investigations of the energy efficiency of the production of winter wheat and sugar beet in Europe. European Journal of Agronomy 11, 35-43.

Küsters, J., 1999. Life cycle approach to nutrient and energy efficiency in European agriculture. The International Fertiliser Society Proceedings No. 438.

Maunder, J.W., 1992. Dictionary of Global Climate Change. UCL Press Limited, London.

Pimentel, D., Hurd, L.E., Bellotti, A.C., Forster, M.J., Oka, I.N., Sholes, O.D., Whitman, R.J., 1973. Food production and the energy crisis. Science 182, 443-449.

Pimentel, D., Hurd, L.E., Belloti, A.C., Forster, M.J., Oka, I.N., Scholes, O.D., Salway, A.G., 1996. UK Greenhouse Gas Emission Inventory 1990-1994. AEA Technology and Department of the Environment. AEA/20092001/Issue 1. ISBN 0-7058-1728-8.

Rathke, G.W., Diepenbrock, H.W., 2003. Energy balances of different crops with rape. In: Proceedings of the 11th International Rapeseed Congress, Copenhagen, Denmark, 6-10 July 2003, pp. 765-768.

Refsgaard, K., Halberg, N., Kristensen, E.S., 1998. Energy utilization in crop and dairy production in organic and conventional livestock production systems. Agricultural Systems 57, 599-630.

Reinhardt, G.A., 1993. Energie-und $\mathrm{CO}_{2}$-Bilanzierung nachwachsender Rohstoffe. Vieweg Verlag, Braunschweig/Wiesbaden.

Richards, I.R., 2000. Energy balances in the growth of oilseed rape for biodiesel and of wheat for bioethanol. Levington Agriculture Report/British Association for Bio Fuels and Oils.

Stephan, C., Kromer, K.H., 1997. Energiebilanz aktueller zuckerrubenproduktions techniken. In: Proceedings of the 60th IIRB Congree, July 1997, Cambridge, UK. 